\title{
Customer Loyalty in Coffee Shop: Literature Review and Condition for the Future
}

\author{
J.A. Pesoa*, B. Kristyanto, and P.K. Dewa
}

\begin{abstract}
The Corona Virus 2019 or Covid-19 outbreak has caused a global panic that is fatal. Various sectors have been affected. The coffee industry sector has also been affected by Covid-19. Losing customer loyalty is a threat to coffee industry entrepreneurs. This study has the purpose of measuring Customer Loyalty and a way to prevent the coffee shops from losing customers during the Covid-19 pandemic. This purpose is divided into two-stage. The first stage is to identify what factors affect customer loyalty and the relationship before the pandemic. The second stage is to test these factors during the Covid-19 pandemic in the context of the coffee shop business area. The second stage will be done for future study purposes. To support the first stage, the author divided it into two steps. First: summarize the factors that affect customer loyalty in the coffee shop business area. The second: is to build a relationship of the factors that affected customer loyalty based on the summarized factor in the first step. The results of this study show that customer satisfaction and trust have a direct effect on customer loyalty. Moreover, these factors can be a suitable mediation for others factors influencing loyalty. Besides that, service quality and price fairness can affected both mediation factors. Moreover, every existing factor also has an important role because these factors influence and support each other in creating Customer Loyalty.
\end{abstract}

Keywords: customer, loyalty, coffee shop, business

Article Info: Received May 21, 2021; Revised September 9, 2021; Accepted September 9, 2021.

\section{INTRODUCTION}

In early 2020 the world was shocked by a new pandemic, namely the Covid-19 Disease. This incident was very unexpected for all countries, one of which was Indonesia. This is something new for Indonesia. The Covid-19 outbreak that hit the whole world has been critically evaluated by the Indonesian government and the World Health Organization (WHO). The government has taken various steps and procedures to prevent its wider spread. The government has declared the Covid-19 outbreak as a national disaster (Sekretariat Kabinet RI, 2020). The Indonesian government has announced various actions in dealing with this problem by always maintaining social distancing or working from home (WFH). Each regional head also contributes to handling covid-19 by issuing various regulations contained in the governor's regulation. Based on the data collected by the 2019 Disease Coronavirus Acceleration and Handling Task Force (Satgas Penanganan Covid19), the number of patients has increased significantly every day (Satuan Tugas Penanganan COVID-19, 2020). Thus making the Indonesian government implemented a policy of limiting community activities or activities (PPKM) to reduce the rate of increase in COVID-19 cases (Sekretariat Presiden, 2021). Pandemic Covid 19 impacted several sectors of human life, one of which is the economic sector (ICO International Coffee Organization, 2020), especially in micro, small and medium enterprises (UMKM), and coffee shops or restaurants are one of these.

Coffee shops and restaurants have experienced a lot of decline in sales or income since this outbreak began, and in order to reduce the spread of this virus, offices,

J.A. Pesoa* is with the Department of Industrial Engineering, Universitas Atma Jaya Yogyakarta, Yogyakarta, Indonesia (email: jalkasihpesoa@gmail.com).

*Corresponding author 
J.A. Pesoa, B. Kristyanto, and P.K. Dewa

coffee shops, and restaurants must close. In a very short period of time, society in terms of coffee consumption outside the home has decreased significantly because more and more countries, one of which Indonesia, have adopted a Full or Partial Lockdown (ICO - International Coffee Organization, 2020). Based on data collected and studied by the ICO 2020, Covid-19 has a significant impact on the global coffee sector (Figure 1). The existence of a pandemic and economic crisis felt by the community has made people switch to the consumption of cheaper sachets. This is a concern for Restaurant and coffee shop industry players, where the loss of customers significantly affects the sustainability of a business during a pandemic. Therefore during the Covid-19 pandemic, a study to prevent customer loss must be conducted. One way that can be done to examine customer losses is to measure customer loyalty. According to Kandampully \& Suhartanto (2000), Customer Loyalty is a customer who makes a purchase back from the same service provider and continues to recommend to others. The loyal customer will increase company profits and become very important in the current pandemic because loyal customers can positively promote the company by word of mouth (Yong-Ki Lee, 2005).

For example, regarding services and how the company handles the Covid-19 pandemic. If the consumer feels that the company is good enough in service and handling Covid-19, then the consumer is willing to buy various company products. In this case, the customer loyalty factor has a vital role for business actors to maintain and develop their business because loyal customers are a major determinant of an organization's long-term financial performance (Jones \& Sasser, 2009). Creating and maintaining customer loyalty helps companies develop mutually beneficial long-term relationships with customers. S. H. Kim et al. (2016) said that the coffee shop is rapidly expanding its market share by attracting new customers and attracting others from competitors. Business people need to produce products and services of excellent quality that can produce very satisfied and loyal customers (Fečiková, 2004). Based on this background, the author has a research question, whether the factors that affect customer loyalty before the pandemic have the same influence during the pandemic or not.

Finally, to answer the research question, the study has the goal of measuring Customer Loyalty and also a way to prevent restaurants and coffee shops from losing customers during the Covid-19 pandemic. In order to conduct the study, the author divided it into two stages. The first stage is to identify what factors affect customer loyalty and the relationship before the pandemic. The second stage is to test these factors during the Covid-19 pandemic in the context of the coffee shop business area. The second stage will be done for future study purposes. To support the first stage in this study, the author divided into two steps, namely, first: to summarize the factors that affect customer loyalty in the coffee shop business area, second: is to build a relationship of the factors that affected customer loyalty based on the summarize factor in the first step.

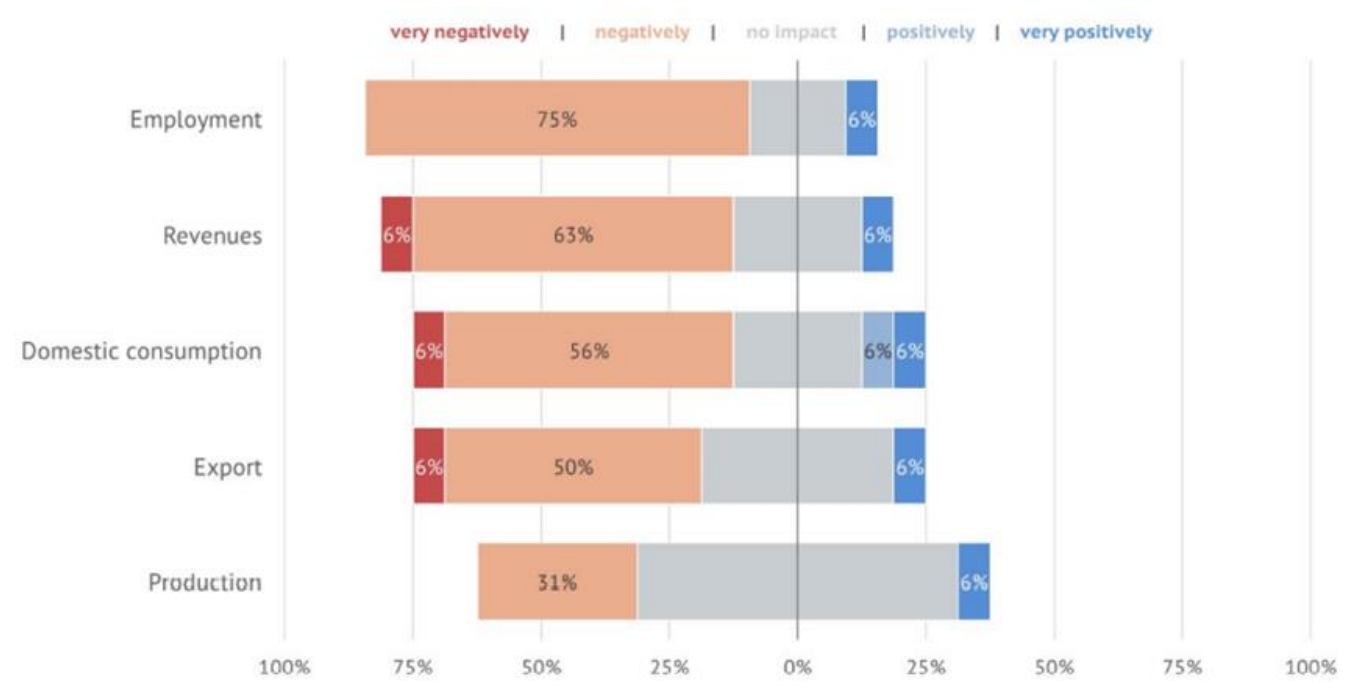

Figure 1. The impact of Covid-19 on the coffee sector (Source:(ICO - International Coffee Organization, 2020)) 


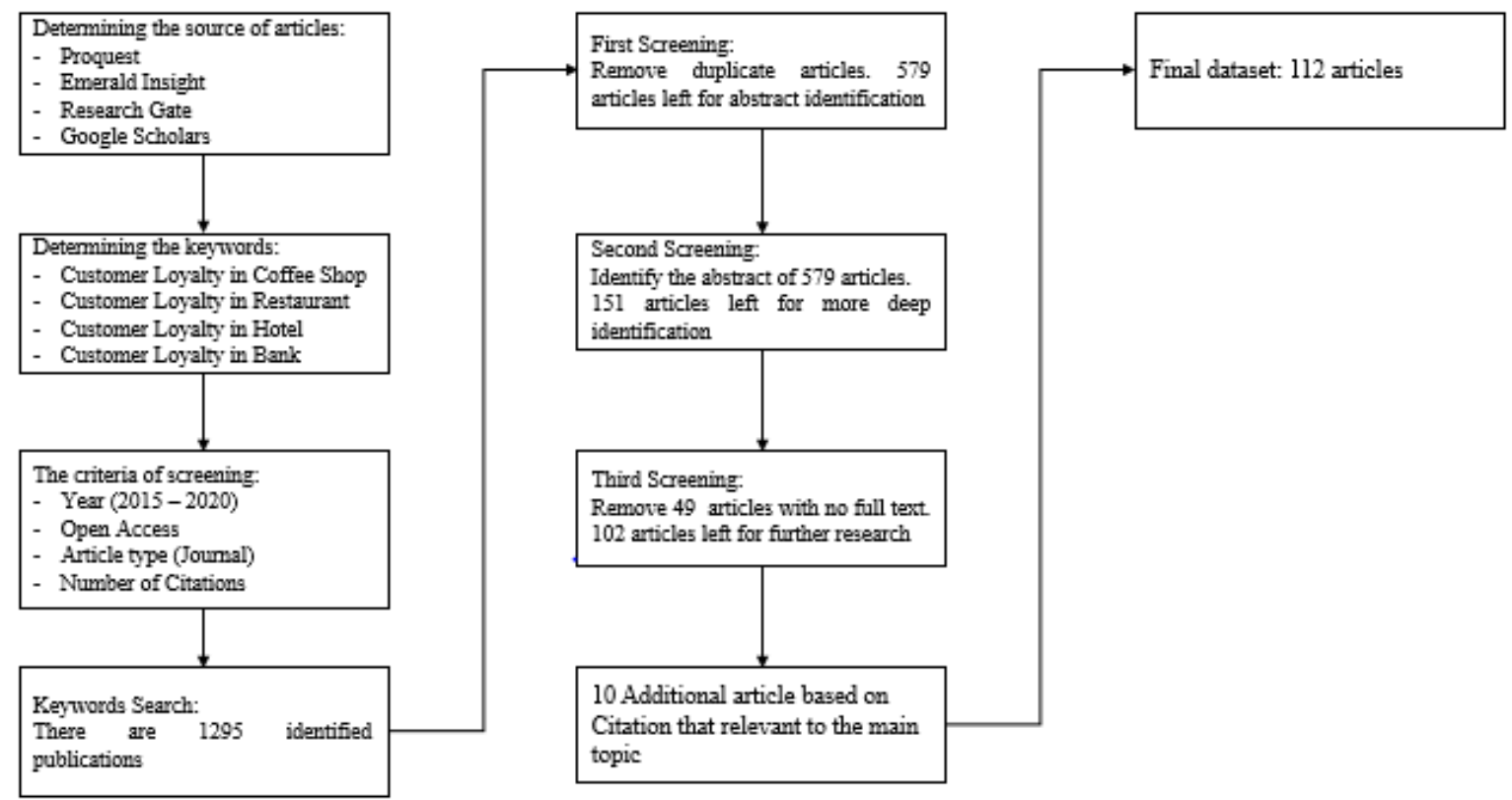

Figure 2. Process of Collecting Articles

\section{RESEARCH METHODOLOGY}

Previously in the introduction already mentioned that this study's topic is about customer loyalty in the coffee shop business. Therefore literature review on customer loyalty is held as the first step to do this study. The author wants to know about customer loyalty from several service business areas. In this study, the service businesses used are coffee shops as the main object of study, restaurants, hotels, and banks. Fink (1998) provides the definition of literature review: "A literature review is a systematic, explicit, and reproducible design for identifying, evaluating, and interpreting the existing body of recorder documents". The literature review usually has two objectives. First, summarize the existing study by identifying the themes, date, and problem. Second, a literature review helps identify the area's conceptual content (Meredith, 1993) and can help in theory development. In this study, the process of collecting the article can be shown in figure 2 .

Collecting articles begins with determining the sources of articles. Author use ProQuest, Emerald Insight, Research Gate, and Google Scholars. The next step is determining the keywords to help the author find the desired articles. Because the topic is about customer loyalty in several service business areas, which are coffee shops, restaurants, hotels, and banks, therefore the keywords are:

- Customer loyalty in a coffee shop

- Customer loyalty in restaurants

- Customer loyalty in bank

- Customer loyalty in hotel

The next step is determining the criteria of articles from 2015 until 2020 to find out the newest updates from articles within that time. Open access also becomes a criterion for looking at the articles because the author does not have access to open for some articles. The following criteria are the type of article which is an international journal. The author uses international journals because they are more valid, and there have been many studies using citations from international journals. The last criterion is the number of citations. This criterion is important because, if many authors cite from a journal, the journal has high quality.

The result of collecting journals is 1295. After eliminating duplicates, 579 are left to evaluate. The author then reviewed the abstract of 579 journals to assess whether the journals were sustainable for the study topic. This reduces the number of journals from 579 to 151 . Forty-nine journals are removed because not have full text, leaving 102 journals for further research. Ten additional articles were added based on the citation that was relevant to the main topic. The final dataset is 112 journals.

\section{LITERATURE REVIEW}

Study on the factors or variables that influence customer loyalty has been widely studied in the product and service business. According to Jogiyanto (2011), a variable is an observation characteristic in a study with different or varying values. There are several kinds of variables which are variable dependent (a variable whose value is influenced by other variables), independent (variables that were affecting dependent variables), control (controlled variable or fixed value), moderator (variables that affect the relationship between the dependent and independent variables), mediator (intermediate variable between dependent and independent variable). Many authors have conducted a study on customer loyalty as a dependent variable with different factors for different business fields such as a 
J.A. Pesoa, B. Kristyanto, and P.K. Dewa

restaurant (Ing et al., 2019; Majid et al., 2018; Haghighi, 2012). A restaurant is a commercially organized place or building that provides good service to all its guests in the form of food and beverages. Apart from looking for profit, the restaurant also has the main objective to satisfy the guests. When a restaurant has made customers feel satisfied, it will produce loyal customers. Customer satisfaction is obtained from many factors, such as good service, good quality food, and the price offered is in accordance with what is expected. Not only that, study on the factors that affect customer satisfaction and customer loyalty has been done a lot. Some studies even try to add several other factors to find the relationship between customer satisfaction and loyalty, as shown in Table 1.

Table 1. Study on Customer Loyalty of Restaurant

\begin{tabular}{|c|c|c|c|}
\hline Author & Variable & Object & Key Findings \\
\hline $\begin{array}{l}\text { Bowden- } \\
\text { Everson et al., } \\
(2013)\end{array}$ & $\begin{array}{l}\text { Independent: Customer } \\
\text { Satisfaction, Trust, Delight } \\
\text { Dependent: Customer Loyalty }\end{array}$ & Restaurant & $\begin{array}{l}\text { In the context of the restaurant } \\
\text { industry, customer satisfaction, } \\
\text { delight, and trust can generate } \\
\text { customer loyalty. }\end{array}$ \\
\hline Martey (2014) & $\begin{array}{l}\text { Independent: Price, Service } \\
\text { Quality, Brand Image, customer } \\
\text { satisfaction } \\
\text { Dependent: Customer loyalty }\end{array}$ & Restaurant & $\begin{array}{l}\text { All independent attributes have a } \\
\text { significant and positive impact on } \\
\text { customer loyalty. In addition, this } \\
\text { study also found that Customer } \\
\text { Relationship Managers (CRMs) can } \\
\text { be used to find out what customers } \\
\text { expect and serve customers better, and } \\
\text { can resolve all customer complaints }\end{array}$ \\
\hline $\begin{array}{l}\text { Heung \& Gu } \\
(2012)\end{array}$ & $\begin{array}{l}\text { Independent: Restaurant } \\
\text { Atmospheric } \\
\text { Mediator: Satisfaction } \\
\text { Dependent: Behavioral Intention }\end{array}$ & Restaurant & $\begin{array}{l}\text { The atmosphere of the restaurant has a } \\
\text { significant impact on customer } \\
\text { satisfaction and intention to return and } \\
\text { spread positive word of mouth }\end{array}$ \\
\hline $\begin{array}{l}\text { Ing et al. } \\
(2019)\end{array}$ & $\begin{array}{l}\text { Independent: Food Quality, } \\
\text { Service Quality, Atmosphere, } \\
\text { Convenience, Price Perception } \\
\text { Mediator: Customer Satisfaction } \\
\text { Moderator: Customer } \\
\text { Innovativeness } \\
\text { Dependent: Customer Loyalty }\end{array}$ & Restaurant & $\begin{array}{l}\text { Overall independent factors have a } \\
\text { positive influence on customer } \\
\text { satisfaction, and price perception is } \\
\text { the strongest predictor. In addition, } \\
\text { customer satisfaction, which is a } \\
\text { mediator, only affects some } \\
\text { relationships. }\end{array}$ \\
\hline $\begin{array}{l}\text { Haghighi } \\
(2012)\end{array}$ & $\begin{array}{l}\text { Independent: Food Quality, } \\
\text { Service Quality, Price, Restaurant } \\
\text { Location, Restaurant Atmosphere } \\
\text { Mediator: Customer Satisfaction, } \\
\text { Customer Trust } \\
\text { Dependent: Customer Loyalty }\end{array}$ & Restaurant & $\begin{array}{l}\text { All independent factor except } \\
\text { Location has a positive impact on } \\
\text { customer satisfaction. Besides that, } \\
\text { food quality is the most important } \\
\text { factor in influencing customer } \\
\text { satisfaction and customer trust }\end{array}$ \\
\hline $\begin{array}{l}\text { Majid et al. } \\
(2018)\end{array}$ & $\begin{array}{l}\text { Independent: Service Quality, } \\
\text { Food Quality, Image } \\
\text { Mediator: - } \\
\text { Dependent: Customer Loyalty }\end{array}$ & Restaurant & $\begin{array}{l}\text { Restaurant service quality is the } \\
\text { biggest contribution. Besides } \\
\text { improving service quality, food } \\
\text { quality and image not only increases } \\
\text { customer loyalty but also helping to } \\
\text { improve the reputation and } \\
\text { sustainability of the restaurant. }\end{array}$ \\
\hline
\end{tabular}


Table 1. (continued)

\begin{tabular}{|c|c|c|c|}
\hline Author & Variable & Object & Key Findings \\
\hline Uddin (2019) & $\begin{array}{l}\text { Independent: Food quality, price, } \\
\text { location \& environment, service } \\
\text { quality } \\
\text { Mediator: customer satisfaction } \\
\text { Dependent: customer loyalty }\end{array}$ & Restaurant & $\begin{array}{l}\text { Food, price, and service quality } \\
\text { variables are positively related to } \\
\text { customer satisfaction, while the } \\
\text { location \& environment variables } \\
\text { have a negative relationship }\end{array}$ \\
\hline $\begin{array}{l}\text { Ryu et al. } \\
(2012)\end{array}$ & $\begin{array}{l}\text { Independent: Physical } \\
\text { Environment, Food Quality, } \\
\text { Service Quality } \\
\text { Mediator: Restaurant Image, } \\
\text { Customer Perceived Value } \\
\text { Moderator: Customer Satisfaction } \\
\text { Dependent: Customer Loyalty }\end{array}$ & Restaurant & $\begin{array}{l}\text { The results of the Structural Equation } \\
\text { modeling show that all independent } \\
\text { factors have a significant impact on } \\
\text { both mediators. In addition, they } \\
\text { prove that perceived value is a } \\
\text { significant determinant of customer } \\
\text { satisfaction }\end{array}$ \\
\hline Albari (2019) & $\begin{array}{l}\text { Independent: Product Quality, } \\
\text { Service Quality, Price } \\
\text { Mediator: Customer Satisfaction } \\
\text { Dependent: Customer Loyalty }\end{array}$ & Restaurant & $\begin{array}{l}\text { All factors have a positive impact on } \\
\text { customer loyalty, either directly or } \\
\text { through customer satisfaction. The } \\
\text { results also show that service quality } \\
\text { has the most significant influence on } \\
\text { customer satisfaction, while the } \\
\text { greatest influence on customer loyalty } \\
\text { is given by product quality }\end{array}$ \\
\hline $\begin{array}{l}\text { Han \& Ryu, } \\
\text { (2009) }\end{array}$ & $\begin{array}{l}\text { Independent: Physical } \\
\text { Environment } \\
\text { Mediator: Price Perception, } \\
\text { Customer Satisfaction } \\
\text { Dependent: Customer Loyalty }\end{array}$ & Restaurant & $\begin{array}{l}\text { The physical environment has a strong } \\
\text { impact on influencing price } \\
\text { perception and customer satisfaction. } \\
\text { Besides, these two mediators play an } \\
\text { important role as a mediator in the } \\
\text { model created. }\end{array}$ \\
\hline
\end{tabular}

Table 2. Study on Customer Loyalty of Hotel

\begin{tabular}{|l|l|l|l|}
\hline \multicolumn{1}{|c|}{ Author } & \multicolumn{1}{|c|}{ Variable } & Object & \multicolumn{1}{c|}{ Key Findings } \\
\hline $\begin{array}{l}\text { Saleem \& Raja } \\
(2014)\end{array}$ & $\begin{array}{l}\text { Independent: Service Quality, } \\
\text { Customer Satisfaction } \\
\text { Mediator: Customer Loyalty } \\
\text { Dependent: Brand Image }\end{array}$ & Hotel & $\begin{array}{l}\text { High service quality will increase customer } \\
\text { satisfaction, so the results will be obtained, } \\
\text { namely strengthening customer loyalty. In } \\
\text { addition, strengthening customer loyalty will } \\
\text { strengthen brand image }\end{array}$ \\
\hline $\begin{array}{l}\text { Cheng \& } \\
\text { Rashid (2013) }\end{array}$ & $\begin{array}{l}\text { Independent: Service Quality, } \\
\text { Customer Satisfaction } \\
\text { Mediator: Corporate image } \\
\text { Dependent: Customer Loyalty }\end{array}$ & Hotel & $\begin{array}{l}\text { The perception of service quality } \\
\text { significantly affects customer satisfaction } \\
\text { and will turn into customer loyalty }\end{array}$ \\
\hline $\begin{array}{l}\text { Gumussoy \& } \\
\text { Koseoglu } \\
(2016)\end{array}$ & $\begin{array}{l}\text { Independent: Service quality, } \\
\text { Perceived value, Perceived price } \\
\text { fairness, Customer satisfaction } \\
\text { Dependent: Customer Loyalty }\end{array}$ & Hotel & $\begin{array}{l}\text { The most significant predictor for customer } \\
\text { loyalty is Customer satisfaction } \\
\text { Perceived value. }\end{array}$ \\
\hline
\end{tabular}


J.A. Pesoa, B. Kristyanto, and P.K. Dewa

The factors tested include Customer Satisfaction (Albari, 2019; Bowden-Everson et al., 2013; Han \& Ryu, 2009; Heung \& Gu, 2012; Ing et al., 2019; Kisang Ryu Hye-Rin Lee, 2012; Martey, 2014; Mohammad Haghighi, 2012), food quality or product quality (Albari, 2019; Ing et al., 2019; Ryu et al., 2012; Majid et al., 2018; Haghighi, 2012), service quality (Albari, 2019; Ing et al., 2019; Kisang Ryu Hye-Rin Lee, 2012; Majid et al., 2018; Martey, 2014; Haghighi, 2012), price (Albari, 2019; Han \& Ryu, 2009; Ing et al., 2019; Martey, 2014; Haghighi, 2012), restaurant location (Haghighi, 2012), atmosphere (Heung \& Gu, 2012; Ing et al., 2019; Haghighi, 2012), and brand image (Ryu et al., 2012; Majid et al., 2018; Martey, 2014)

In Table 2, it can be seen that the results obtained by a previous study using various factors have a positive and significant effect on customer loyalty. Study in customer loyalty is not limited to the restaurant industry, but loyalty is also vital for the hotel industry (Gumussoy \& Koseoglu, 2016; Jasinskas et al., 2016; Saleem \& Raja, 2014). The hotel business can generate a profit by satisfying its customers (Saleem \& Raja, 2014) because hotel customers who are satisfied with what is offered by the hotel have a high tendency to become loyal customers.

Loyal customers are a very important and valuable asset for a hotel organization. Currently, hotel selection is one of the most discussed topics, both in terms of service, price, and quality. Most hoteliers use the same or similar services. Therefore it is essential not only to attract customers but also to retain customers as well (Jasinskas et al., 2016). Therefore, several studies try to reveal ways to retain hotel customers, namely by testing customer loyalty. In testing Customer Loyalty in the hotel industry, several studies have tried to use several combinations of factors, including Service Quality (Cheng \& Rashid, 2013; Gumussoy \& Koseoglu, 2016; Kandampully \& hu, 2007; Saleem \& Raja, 2014), Customer Satisfaction (Cheng \& Rashid, 2013; Gumussoy \& Koseoglu, 2016; Kandampully \& hu, 2007; Saleem \& Raja, 2014), Price (Gumussoy \& Koseoglu, 2016), Perceived value (Gumussoy \& Koseoglu, 2016), Corporate Image (Cheng \& Rashid, 2013; Kandampully \& hu, 2007; Saleem \& Raja, 2014).

The literature review of customer loyalty in banks (Abror et al., 2019; Khan \& Fasih, 2014; Kheng et al., 2010). One of the business service sectors developing in this modern era is the banking sector in Table 3. Various competitors from new companies have emerged that offer various kinds of products and services to attract new customers. Competition is very tight in seizing customers from competitors, requiring the Bank to manage their business services properly. One of the important factors in managing a service business such as a bank is increasing customer loyalty (Bruneau et al., 2018). When a customer is loyal to a product or brand, he is more likely to buy or recommend the product to others (Abror et al., 2019). This has brought interest for the author to test customer loyalty in the banking sector.

Table 3. Study on Customer Loyalty of Bank

\begin{tabular}{|c|c|c|c|c|}
\hline Author & Variable & Method & Object & Key Findings \\
\hline $\begin{array}{l}\text { Khan \& Fasih } \\
(2014)\end{array}$ & $\begin{array}{l}\text { Independent: Service Quality } \\
\text { Dependent: Customer } \\
\text { Satisfaction, Customer } \\
\text { Loyalty }\end{array}$ & Survey & Bank & $\begin{array}{l}\text { The overall dimensions of service } \\
\text { quality have a significant and positive } \\
\text { effect on both customer loyalty and } \\
\text { customer satisfaction }\end{array}$ \\
\hline $\begin{array}{l}\text { Mang'unyi et } \\
\text { al. (2018) }\end{array}$ & $\begin{array}{l}\text { Independent: e-CRM } \\
\text { Mediator: Customer } \\
\text { Satisfaction } \\
\text { Dependent: Customer Loyalty }\end{array}$ & Survey & Bank & $\begin{array}{l}\text { There is a significant interaction } \\
\text { between e-CRM and Customer } \\
\text { Satisfaction in influencing customer } \\
\text { loyalty. }\end{array}$ \\
\hline $\begin{array}{l}\text { Abror et al. ( } \\
\text { 2019) }\end{array}$ & $\begin{array}{l}\text { Independent: } \\
\text { Religiosity, } \quad \text { Customer } \\
\text { Engagement, } \quad \text { Customer } \\
\text { Satisfaction } \\
\text { Dependent: Customer Loyalty }\end{array}$ & Survey & Bank & $\begin{array}{l}\text { Service quality has a positive impact on } \\
\text { customer satisfaction, and religiosity } \\
\text { has a negative impact as a mediator } \\
\text { between service quality and customer } \\
\text { satisfaction. Furthermore, customer } \\
\text { engagement has a significant effect on } \\
\text { customer loyalty }\end{array}$ \\
\hline
\end{tabular}


Table 4. Study on Customer Loyalty of Coffee Shop

\begin{tabular}{|c|c|c|c|}
\hline Author & Variable & Object & Key Findings \\
\hline $\begin{array}{l}\text { Pleshko \& } \\
\text { Heiens (2015) }\end{array}$ & $\begin{array}{l}\text { Independent: Customer } \\
\text { Satisfaction } \\
\text { Dependent: Customer } \\
\text { Loyalty }\end{array}$ & $\begin{array}{l}\text { Coffee } \\
\text { Shop }\end{array}$ & $\begin{array}{l}\text { Satisfied customers are not necessarily } \\
\text { loyal customers because they are loyal to } \\
\text { other competitors }\end{array}$ \\
\hline $\begin{array}{l}\text { Dhisasmito \& } \\
\text { Kumar, (2020) }\end{array}$ & $\begin{array}{l}\text { Independent: Service } \\
\text { quality, Store atmosphere, } \\
\text { Price Fairness } \\
\text { Mediator: Customer } \\
\text { Satisfaction } \\
\text { Dependent: Customer } \\
\text { Loyalty }\end{array}$ & $\begin{array}{l}\text { Coffee } \\
\text { Shop }\end{array}$ & $\begin{array}{l}\text { All dimensions of service quality } \\
\text { (tangible, reliability, responsiveness, } \\
\text { assurance, and empathy), as well as price } \\
\text { fairness, play a critical role in the coffee } \\
\text { shop industry in Indonesia because they can } \\
\text { create customer loyalty }\end{array}$ \\
\hline $\begin{array}{l}\text { Lee et al. } \\
(2018)\end{array}$ & $\begin{array}{ll}\text { Independent: } & \\
\text { atmosphere, } & \text { employee } \\
\text { attitudes, IT } & \text { service, } \\
\text { coffee quality } & \\
\text { Mediator: } & \text { Customer } \\
\text { satisfaction } & \\
\begin{array}{l}\text { Dependent: } \\
\text { loyalty }\end{array} & \text { Customer } \\
& \end{array}$ & $\begin{array}{l}\text { Coffee } \\
\text { Shop }\end{array}$ & $\begin{array}{l}\text { In particular, coffee taste is the attribute } \\
\text { that has the most influence on satisfaction. } \\
\text { furthermore, the relationship between } \\
\text { customer satisfaction and customer loyalty } \\
\text { is also explained }\end{array}$ \\
\hline $\begin{array}{l}\text { Susanty \& } \\
\text { Kenny, (2015) }\end{array}$ & $\begin{array}{l}\text { Independent: Staff } \\
\text { behavior, Physical quality, } \\
\text { ideal self-congruence, } \\
\text { brand identification, } \\
\text { lifestyle congruence. } \\
\text { Mediator: Customer } \\
\text { Satisfaction } \\
\text { Dependent: } \\
\text { Loyalty }\end{array}$ & $\begin{array}{l}\text { Coffee } \\
\text { Shop }\end{array}$ & $\begin{array}{l}\text { Variables that affect the two coffee shop } \\
\text { objects are different. However, customer } \\
\text { satisfaction has an effect on both coffee } \\
\text { shops }\end{array}$ \\
\hline $\begin{array}{l}\text { Shin et al. } \\
\text { (2015) }\end{array}$ & $\begin{array}{ll}\text { Independent: } & \text { Service } \\
\text { Quality, Atmosphere } \\
\text { Mediator: Customer } \\
\text { Satisfaction } & \\
\text { Dependent: } & \text { Customer } \\
\text { Loyalty } & \\
\end{array}$ & $\begin{array}{l}\text { Coffee } \\
\text { Shop }\end{array}$ & $\begin{array}{l}\text { Taste is the factor that most influences } \\
\text { service quality and customer loyalty }\end{array}$ \\
\hline $\begin{array}{l}\text { Mohamud et al. } \\
\text { (2017) }\end{array}$ & $\begin{array}{lr}\text { Independent: } & \text { Service } \\
\text { quality, price } & \text { acceptance, } \\
\text { trust, } & \text { customer } \\
\text { satisfaction } & \\
\text { Dependent: } & \text { Behavioral } \\
\text { Intentions }\end{array}$ & $\begin{array}{l}\text { Coffee } \\
\text { Shop }\end{array}$ & $\begin{array}{l}\text { All independent variables have a direct } \\
\text { impact on behavioral intentions, although } \\
\text { tangibles and empathy have a negative } \\
\text { impact }\end{array}$ \\
\hline $\begin{array}{l}\text { Suhud et al. } \\
(2020)\end{array}$ & $\begin{array}{ll}\text { Independent: } & \text { Product } \\
\text { quality, service } & \text { quality, } \\
\text { price } & \\
\text { Dependent: } & \text { Customer } \\
\text { Satisfaction } & \end{array}$ & $\begin{array}{l}\text { Coffee } \\
\text { Shop }\end{array}$ & $\begin{array}{l}\text { This study found that the independent } \\
\text { variable used was insignificantly affected } \\
\text { customer satisfaction. And this study also } \\
\text { provides three models that have been } \\
\text { modified to examine each predictor variable }\end{array}$ \\
\hline
\end{tabular}

One of the business sectors that is growing rapidly today is the coffee shop industry sector. The study results of TOFIN, a company providing business solutions in the form of goods and services in the HOREKA industry (Hotels, restaurants, and cafes), together with MIX MarComm Magazine, noted that the number of coffee shops in Indonesia in August 2019 reached more than 2,950 outlets. That number has increased by around 1,950 outlets from 2016, only around 1000 outlets (Toffin, 2020). Not only in big cities, even small cities already have many coffee shops that spread even though they have different standards and markets. The emergence of the trend of hanging out in coffee shops is very popular in various circles. A coffee shop is a place that provides various types of coffee and other non-alcoholic drinks in a relaxed, comfortable place, and is equipped with music, either through a player or live music, provides television and 
J.A. Pesoa, B. Kristyanto, and P.K. Dewa

reading, interior design, friendly service, and several among them provide a wireless internet connection. Coffee shops are also nowadays not only a place to enjoy coffee but also a place to do assignments, a place to take pictures, a place to meet colleagues. The growth of coffee shops in Indonesia is inseparable from the competition, so they must carry out a strategy that can attract customers and build a good image, trying to satisfy consumers with what is offered to gain customer loyalty.

There have been many studies using the coffee shop as an object to examine customer loyalty. In table 4 , it can be seen that there are various combinations of variables in testing customer loyalty, including Customer Satisfaction (Dhisasmito \& Kumar, 2020; Lee et al., 2018; Mohamud et al., 2017; Pleshko \& Heiens, 2015; Shin et al., 2015; Suhud et al., 2020; Susanty \& Kenny, 2015), Service Quality (Dhisasmito \& Kumar, 2020; Lee et al., 2018; Mohamud et al., 2017; Shin et al., 2015; Suhud et al., 2020), Atmosphere (Dhisasmito \& Kumar, 2020; Lee et al., 2018; Shin et al., 2015), Price (Dhisasmito \& Kumar, 2020; Mohamud et al., 2017; Suhud et al., 2020).

The literature review results on the variables that cause customer loyalty in every business field can be seen in table 5 .

Table 5. Factors affecting Customer Loyalty in Several Business

\begin{tabular}{|c|c|c|c|}
\hline \multicolumn{4}{|c|}{ Factors affecting customer loyalty on several Business } \\
\hline Restaurant & Hotel & Bank & Coffee shop \\
\hline $\begin{array}{l}\text { Customer } \\
\text { Satisfaction }\end{array}$ & Service Quality & $\begin{array}{l}\text { Customer } \\
\text { Satisfaction }\end{array}$ & $\begin{array}{l}\text { Customer } \\
\text { Satisfaction }\end{array}$ \\
\hline Food Quality & $\begin{array}{l}\text { Customer } \\
\text { Satisfaction }\end{array}$ & $\begin{array}{l}\text { Service } \\
\text { Quality }\end{array}$ & Service Quality \\
\hline Service Quality & Brand Image & $\begin{array}{c}\text { Customer } \\
\text { Engagement }\end{array}$ & Atmosphere \\
\hline Price & Price & Religiosity & Price \\
\hline Environment & Perceived Value & & Trust \\
\hline Atmosphere & & & Product Quality \\
\hline Convenience & & & $\begin{array}{l}\text { Employee } \\
\text { Attitude }\end{array}$ \\
\hline Perceived Value & & & IT Service \\
\hline Brand Image & & & Environment \\
\hline Delight & & & Brand \\
\hline \multirow[t]{7}{*}{ Trust } & & & $\begin{array}{r}\text { Content } \\
\text { Functional }\end{array}$ \\
\hline & & & Content Sensory \\
\hline & & & $\begin{array}{c}\text { lifestyle } \\
\text { congruence }\end{array}$ \\
\hline & & & Staff Behavior \\
\hline & & & $\begin{array}{l}\text { Ideal Self- } \\
\text { congruence }\end{array}$ \\
\hline & & & Physical quality \\
\hline & & & Packaging \\
\hline
\end{tabular}




\section{ANALYSIS}

\subsection{Summarize Factors}

One of the objectives of this study is to summarize the factors that affect customer loyalty in the coffee shop business area. The author tries to conclude the factors that have been discussed previously in the literature review section. Based on the literature review results in Table 5, it can be seen that in any business field, customer loyalty is influenced by many factors. However, it also has similarities in every business field. Therefore according to the author, it is necessary to summarize these factors because the use of too many factors in testing customer loyalty can lead to errors of author and respondents in understanding factors and difficulties in analyzing and processing data, so there is a need for simplification and general merging. Therefore, the author tries to summarize and combine these factors into nine factors: Customer Satisfaction, Service Quality, Product Quality, Price, Trust, Brand Image, Employee Attitude, Atmosphere \& Environment, and Customer Engagement in the context of the coffee shop business.

First: Customer satisfaction is the first factor because, in every business sector, customer satisfaction is the most factor often used in testing customer loyalty. In addition, this factor cannot be combined with others because customer satisfaction is a suitable mediation or effect of other factors on customer loyalty as in studies (Ing et al., 2019; Sia \& Subagio, 2013). Second: Factors IT service are then categorized as service quality. IT service can be the availability or speed of wireless internet service (Lee et al., 2018). According to Bulut et al., 2015; Honack \& Waikar (2017), the free internet WIFI service can improve the service quality of a coffee shop because many of the customers come to find and access free internet. Third: a functional and sensory content factor is combined into the product quality factor because the explanation of applicable content, according to Wang \& $\mathrm{Yu}$ (2016), is related to the ingredients contained in a product, such as ingredients, thirst-quenching ability, and calorie content. Wang \& $\mathrm{Yu}$ (2016) also mentioned that sensory content is taste, sugariness, and homogeneity. According to Wang \& Yu (2016), packaging factors contain color, size, and graphics. Most people find it easier to recognize the packaging of a product than the taste of the product (Me'ndez et al., 2011). Good and attractive packaging can improve product quality. These are the things that make the content and packaging factors categorized as product quality. Forth: there are the factors of staff behavior, Employee attitude, and staff friendliness. These factors both discuss the attitude, character, or behavior of a coffee shop worker towards customers. Therefore, the author combines them into the Employee attitude factor. Fifth: the next factor is Atmosphere \& Environment. This factor is combined together because, according to the author, these factors both talk about the situation around the coffee shop. This can be proven by Heung \& Gu (2012) and Han \& Ryu (2009). Heung \& $\mathrm{Gu}$ (2012) talk about the dimension of atmosphere, for example, attractive design \& décor, ambiance, and spatial layout. This dimension is similar to Han \& Ryu (2009) in that dimensions of the environment are attractive décor and artifacts, spatial layout, and ambient conditions.

Sixth: is the trust factor, where this factor cannot be combined with another factor because trust is the effect of something. It can be the effect of good service, good products, or satisfaction with the environment, etc. Therefore, the author assumes trust as a factor that will influence customer loyalty in a coffee shop, as in a study by (W. G. Kim et al., 2009; Mohamud et al., 2017). Seventh: The price factor cannot be combined with other factors because only this factor talks about money transactions and cannot be combined with others. Eighth: The next factors that are combined are the factors of lifestyle congruence, ideal self-congruence, and convenience. The author incorporates it into Customer Engagement (CE) factors because these three factors talk about the role of the customer itself towards customer loyalty of a product or company. Ninth: The last factor that is considered to influence customer loyalty is the Brand Image factor, which is an important factor in increasing an organization's marketing activities. Because brand image through various ways such as advertisement, word of mouth, public relations, physical image, and actual experience can influence customer's mind (Normann, 1991).

\subsection{Summarize Factors}

The factor most often discussed when talking about customer loyalty is customer satisfaction. Customer satisfaction is considered the most important factor in a business and is one of a company's goals. Satisfied customers enable a company to get repurchase intentions from customers (Pleshko \& Heiens, 2015). The key for a company to survive in the market competition is the retention of satisfied customers (Fečiková, 2004) with the services or products provided. (Kandampully \& Suhartanto, 2000) Stated that when customers are satisfied with the products or services provided, there will be a positive relationship between customer satisfaction and customer loyalty. Therefore, the main factor in a company to get loyalty is to maintain and get customer satisfaction. There have been many studies discussing the effect of customer satisfaction on customer loyalty. However, not always a satisfied customer is a loyal customer (Pleshko \& Heiens, 2015). Therefore a combination of other factors is needed.

Besides being a factor causing customer loyalty, customer satisfaction also acts as a mediator or an intermediary for other factors, such as service quality. Abror et al., 2019; Kususmasasti et al. (2017) revealed that service quality significantly affects customer satisfaction. A customer will feel satisfied when he gets good service. For example, services at a bank are said to have good service when the bank helps customers make transactions. Besides that, more important is building good relationships with customers (Abror et al., 2019). Likewise, the service at a coffee shop is said to be good when a customer gets good and friendly service from a 
barista. Having customers satisfied with the services provided makes it possible to use these services or products again and again and recommend them to others. Therefore service quality is an important factor to affect customer loyalty and using customer satisfaction as the mediation (Miranda et al., 2018). In creating good service quality, the role of the Employee Attitude factor is also important. Employees of the organization play an important role in shaping customer perceptions and satisfaction because they (staff) are responsible for providing exemplary service in accordance with customer expectations (Zeithaml et al., 1988). As employees, they must have good communication skills. Therefore, when opening job vacancies, many companies always emphasize the criteria for prospective staff to have good communication skills. Because staff/employees who have low communication skills are likely to be able to overcome emotional problems that risk the image of the organization is very low (Susanty \& Kenny, 2015). Besides being required to have good communication skills, the staff is also required to have kindness and friendly attitudes (Lee et al., 2018). For example, they were listening to and following up on customer complaints well, helping in suggesting the menu.

Besides, service quality is influenced by employee attitude; Abror et al. (2019), Ahn \& Back (2018), and Roy et al. (2018) has confirmed that there is a significant effect between service quality and customer engagement factor. Therefore, Abror et al. (2019) argue that when a customer gets better service quality and turns into satisfying, it means that the customers have met with the brand experience. They have a willingness to engage with the product or brand offered. In addition, in cultivating relationships with customers, customer engagement is one of the main topics that is often discussed, where CE is the customer's attitude towards a brand or company/organization (Bijmolt et al., 2017). Recommending a product, service, or brand can be done by viral marketing activities, where this activity involves the customer as the leading actor in recommending something to others (Brodie et al., 2011). This is usually done by artists or celebrities who often review a product and recommend a product or brand through social media and encourage other people to try the product or brand. For example, the famous coffee brand today is Starbucks, where this brand is famous, one of which is because of the role of the customer in promoting the product. The customers involved can also play an important role in the development of new products or services (Hoyer et al., 2010).

The results of Ha \& Jang (2010) show a positive relationship between several factors, such as service quality, employee attitude, product quality, and store atmosphere. The author got the result that customers with a low perception of the atmosphere are better to apply good employee service to increase satisfaction and loyalty than the customer with high perception. Then providing good quality food is essential to creating customer satisfaction in a restaurant where the atmosphere is unsatisfactory. The next factor is product quality. The quality of a product is essential, especially in the food and beverage industry, for example, restaurants and coffee shops. The things that are meant by product quality are ingredients, calorie content, sugariness (Wang \& Yu, 2016), taste (Mohamud et al., 2017), and packaging (Me'ndez et al., 2011). A study that discusses product quality has different results; Kususmasasti et al. (2017) and Peng \& Chen (2015) found that product quality does not have an effect on customer loyalty satisfaction.

Contrary to Parsa et al. (2012) and Shin et al. (2015), a product's quality plays an important role in customer satisfaction and loyalty. Based on the different results from Kususmasasti et al. (2017) and Peng \& Chen (2015), with Parsa et al. (2012) and Shin et al. (2015), it can be concluded that the quality of food depends on the needs of each customer and also the destination. When viewed in terms of customer needs just for eating or customers who like to travel food, a restaurant is highly demanded to have good quality food. For food lovers, the most important thing is the food quality, which will make these customers recommend to others. Furthermore, suppose the customer's destination is a coffee shop. In that case, the product quality does not affect customer loyalty, because according to a depth interview conducted by Kususmasasti et al. (2017) that the quality or variety of a coffee shop product has no effect on customer loyalty because most of the characteristics of the customer are shifting moved to try the new atmosphere from another coffee shop, where most coffee shop customers do not just enjoy their coffee but do various activities such as doing assignments, hanging out, and reading. Supporting this statement, the atmosphere and environmental factors are essential for a coffee shop because most customers who visit a coffee shop will feel satisfied with the atmosphere and environment offered. Therefore, the owner or manager should create the proper atmosphere based on the theme of the coffee shop (Lee et al., 2018). The owner or manager can enhance background music, indoor illumination, and temperature, and the scents (Shin et al., 2015), clean and colorful sofas, clean places (W. G. Kim et al., 2009), spatial-layouts, décors and artifacts (Han \& Ryu, 2009).

All of these factors will increase students' intention and interest in learning. In line with customer needs, which is just hanging out or studying, the atmosphere and environment will be the main keys for customers to come back to visit. By enhancing a good atmosphere and environment, it will generate an emotional effect on customers with a view to increasing the probability of buying. (Mafini \& Dhurup, 2015) Atmospherics are also important for forming first impressions and influencing consumers' perceptions of a store, and it also has an impact on a store's image. Therefore atmospheric and environment have a positive relationship with the store image. Developing and enhancing the store's brand image is also important to get loyal customers. A good store image can affect customer perceptions of their decision to purchase (Kandampully \& Suhartanto, 2000). Some customers will feel very proud and feel 
satisfied when buying a branded product, and this will affect the perception of other people to buy the same product.

The effect of increasing the brand image of an organization is to get high customer trust (Tan et al., 2011). Trust is believed to be an important contributor to customer loyalty to the organization (Garbarino \& Johnson, 1999). Customer trust in an organization is essential and is part of a business plan to build relationships with customers long-term (Mohamud et al., 2017). Coffee shop managers can increase trust in ways such as provide good service to customer requests, respond promptly to customer inquiries, offer fast service, respond promptly to customer requests, help customers sincerely, respond to customer requests accurately, and provide confidence in the raw materials used and the procedures to cooking (Shin et al., 2015). When customers find employees very caring and responsive to their needs quickly, then the customer will get a sense of trust (Mohamud et al., 2017). Therefore it can be said that there is a positive relationship between service quality and trust to produce loyal customers. In addition, a positive relationship is also given by trust and price for customer loyalty. This is because trust also gives customers the tendency to receive a higher price when a company can be trusted (Chaudhuri \& Holbrook, 2001)

Loyal customers can also be seen from the customer's intention to visit again. Most of the study results indicate that the factor that causes a customer to revisit intention is price. (W. G. Kim et al., 2009) Said that the price factor has an important role in determining customer revisit intention compared to service quality for students. Because most of the visitors to a coffee shop or restaurant are students, financial factors are crucial for students. Moreover, in order to still be able to feel and enjoy a coffee shop, the main factor that is taken into consideration is the price factor. There are also customers that will pay more to enjoy the atmosphere or physical environment, such as decorations and artifacts, which in turn will influence consumers to perceive prices (Han \& Ryu, 2009), For example, when consumers think the prices in this place are reasonable or the prices charged by this place according to what is offered. It shows that there is a relationship between price and atmosphere. Therefore, the relationship model between each factor towards customer loyalty is as follows in figure 3 .

Based on figure 3 , these factors will be used to measure and analyze customer loyalty during the Covid19 pandemic. The reason for using the factors in Figure 3 is that the author argues that the factors will have a positive impact and can increase customer loyalty during the Covid-19 pandemic, for example, factors price. Currently, people's incomes are decreased due to covid-19 (Databoks, 2021), and it will reduce consumer buying interest. Therefore the price factor becomes a consideration to increase customer loyalty. Product quality is also important to measure customer loyalty. According to an article from Katadata (2020), the manager or owner of a coffee shop will compete to get the customer by offering good quality of product and affordable price. Therefore increasing the quality of a product will greatly impact the getting of loyal customers, and it will be a consideration of the customer is enjoying the food. Besides the product quality, service quality and cleanliness are also a consideration for the customer to enjoy their food. According to an article published by Institut Teknologi Kesehatan Malang Widya Cipta Husada (2021), the Covid-19 pandemic has made people increase their awareness and keep the cleanliness of hands and foods to be consumed.

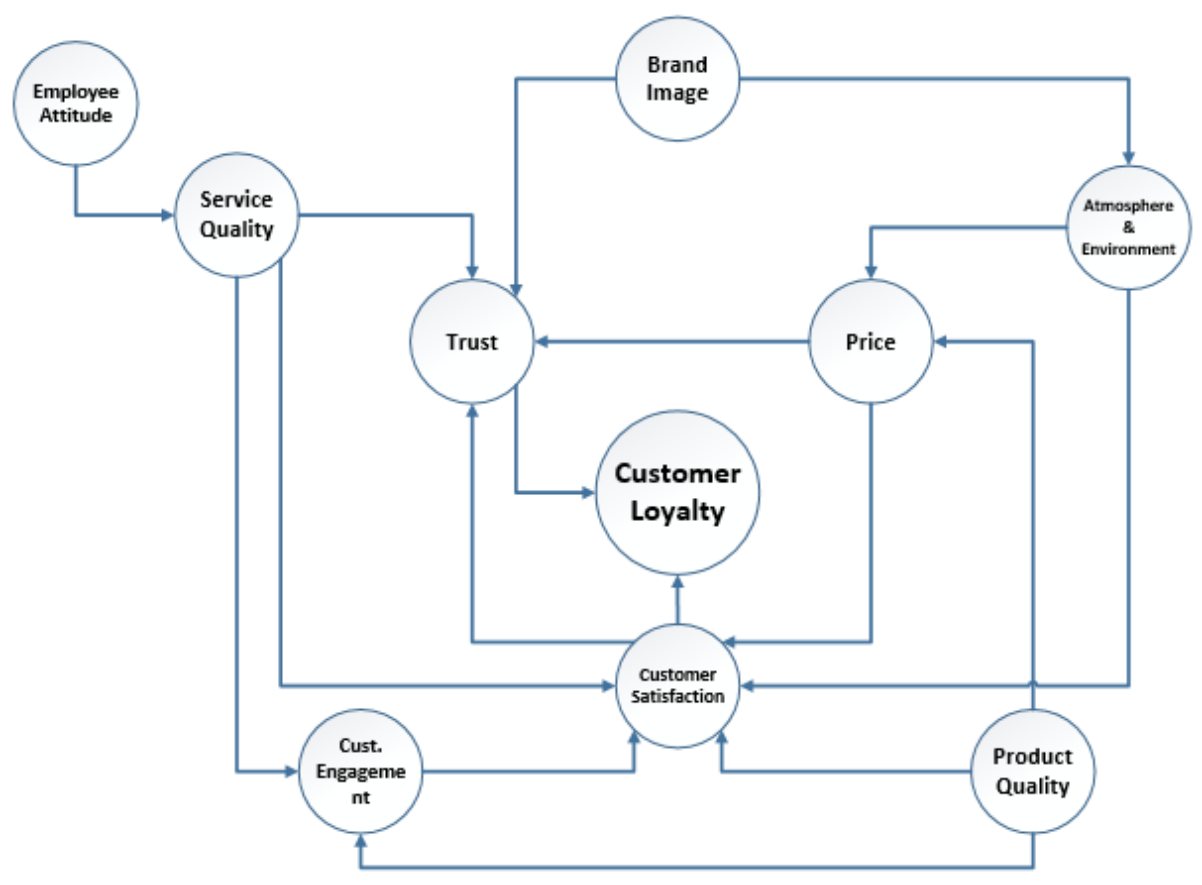

Figure 3. Relationship between factors to customer loyalty 
Every place must implement the health protocols that the government has set. The desire and vigilance of consumers for services during the Covid-19 pandemic is undoubtedly increasing. The increasing consumer demand for services will cause companies to provide the best service, and they must have ideas and creativity to maintain customer satisfaction. Improving service quality to satisfy customers is one of the goals for every company. Therefore, the variables of service quality, trust, customer satisfaction, brand image, customer engagement, and even the environment are considered important to measure customer loyalty during the COVID-19 pandemic.

\section{CONCLUSION}

Based on the result, the author concludes that the factors that will be used to measure customer loyalty are the summarized factor in figure 2, which are divided into nine factors: Customer Satisfaction, Service Quality, Product Quality, Price, Trust, Brand Image, Employee Attitude, Atmosphere \& Environment, and Customer Engagement. The author believes that these factors will have a significant impact on influencing customer loyalty during the COVID-19 pandemic. From the relationship in Figure 2, it can be seen that the factors that directly affect customer loyalty are Customer Satisfaction, Trust, and Price. This shows that when customers are satisfied with what has been offered and believe in the coffee shop, it will significantly affect the loyalty of customers who come to visit. In addition, Customer Satisfaction, Trust, and price can be suitable mediation for other factors such as Atmosphere \& Environment, Brand Image, Service Quality, Employee Attitude, Customer Engagement, and Product Quality. Then Customer Satisfaction is the most influenced factor and influences other factors, proving that Customer Satisfaction is the most dominant factor and acts as a mediator of other factors in influencing customer loyalty. Besides, every existing factor also has an important role because these factors influence and support each other in creating Customer Loyalty.

The purpose of this study is divided into two-stage. The first stage is to determine what factors affect customer loyalty, and the first stage is already done in this study. The second stage is to test the factors during the Covid-19 pandemic, and it will be done for future study purposes. For the future study, the factors that will be used to test customer loyalty during Covid-19 are the nine factors that have already been summarized.

\section{REFERENCES}

Abror, A., Patrisia, D., Engriani, Y., Evanita, S., Yasri, Y., \& Dastgir, S. (2019). Service quality, religiosity, customer satisfaction, customer engagement and Islamic bank's customer loyalty. Journal of Islamic Marketing, 11(6), 1691-1705.

Ahn, J., \& Back, K. J. (2018). Antecedents and consequences of customer brand engagement in integrated resorts. International Journal of Hospitality Management, 75, 144-152.

Albari. (2019). The Influence of Product Quality, Service Quality and Price on Customer Satisfaction and Loyalty. Asian Journal of Entrepreneurship and Family Business, 3(1), 49-64.

Bijmolt, T. H. A., Krafft, M., Sese, F. J., \& Viswanathan, V. (2017). Multi-tier Loyalty Programs to Stimulate Customer Engagement. Customer Engagement Marketing, 10, 119-139.

Bowden-Everson, J. L. H., Dagger, T. S., \& Elliott, G. (2013). Engaging Customers for Loyalty in the Restaurant Industry: The Role of Satisfaction, Trust, and Delight. Journal of Foodservice Business Research, 16(1), 52-75.

Brodie, R. J., Hollebeek, L. D., Jurić, B., \& Ilić, A. (2011). Customer engagement: Conceptual domain, fundamental propositions, and implications for research. Journal of Service Research, 14(3), 252271.

Bruneau, V., Swaen, V., \& Zidda, P. (2018). Are loyalty program members really engaged? Measuring customer engagement with loyalty programs. Journal of Business Research, 91, 144-158.

Bulut, M. F., Demirbas, M., \& Ferhatosmanoglu, H. (2015). LineKing: Coffee Shop Wait-Time Monitoring Using Smartphones. IEEE Transactions on Mobile Computing, 14(10), 2045-2058.

Chaudhuri, A., \& Holbrook, M. B. (2001). The chain of effects from brand trust and brand affect to brand performance: The role of brand loyalty. Journal of Marketing, 65(2), 81-93.

Cheng, B. L., \& Rashid, M. Z. A. (2013). Service quality and the mediating effect of corporate image on the relationship between customer satisfaction and customer loyalty in the Malaysian hotel industry. Gadjah Mada International Journal of Business, 15(2), 99-112.

Databoks (2021). Survei: Masyarakat yang Alami Penurunan Pendapatan Akibat Covid-19 Meningkat. Availabe at: https://ataboks.katadata.co.id/datapublish/2021/02/ 23/survei-masyarakat-yang-alami-penurunanpendapatan-akibat-covid-19-meningkat

Dhisasmito, P. P., \& Kumar, S. (2020). Understanding customer loyalty in the coffee shop industry (A survey in Jakarta, Indonesia). British Food Journal, 122(7), 2253-2271.

Fečiková, I. (2004). An index method for measurement of customer satisfaction. TQM Magazine, 16(1), 5766. 
Fink A. (1998). Conducting research literature reviews: from paper to the internet. USA: SAGE Publications, Inc.

Garbarino, E., \& Johnson, M. S. (1999). The different roles of satisfaction, trust, and commitment in customer relationships. Journal of Marketing, 63(2), 70-87.

Gumussoy, C. A., \& Koseoglu, B. (2016). The Effects of Service Quality, Perceived Value and Price Fairness on Hotel Customers' Satisfaction and Loyalty. Journal of Economics, Business and Management, 4(9), 523-527.

Ha, J., \& Jang, S. C. (2010). Effects of service quality and food quality: The moderating role of atmospherics in an ethnic restaurant segment. International Journal of Hospitality Management, 29(3), 520-529.

Haghighi, M. (2012). Evaluation of factors affecting customer loyalty in the restaurant industry. African Journal of Business Management, 6(14), 5039-5046.

Han, H., \& Ryu, K. (2009). The roles of the physical environment, price perception, and customer satisfaction in determining customer loyalty in the restaurant industry. Journal of Hospitality and Tourism Research, 33(4), 487-510.

Heung, V. C. S., \& Gu, T. (2012). Influence of restaurant atmospherics on patron satisfaction and behavioral intentions. International Journal of Hospitality Management, 31(4), 1167-1177.

Honack, R., \& Waikar, S. (2017). Growing Big While Staying Small: Starbucks Harvests International Growth. Kellogg School of Management Cases, 1(1), $1-22$.

Hoyer, W. D., Chandy, R., Dorotic, M., Krafft, M., \& Singh, S. S. (2010). Consumer cocreation in new product development. Journal of Service Research, 13(3), 283-296.

ICO - International Coffee Organization. (2020). Impact of covid-19 on the global coffee sector: the demand side. American Health \& Drug Benefits, 13(3), 1-9. http://www.ncbi.nlm.nih.gov/pubmed/32699574\%0 Ahttp://www.pubmedcentral.nih.gov/articlerender.fc gi?artid=PMC7370821

Ing, P. G., Zheng Lin, N., Xu, M., \& Thurasamy, R. (2019). Customer loyalty in Sabah full-service restaurant. Asia Pacific Journal of Marketing and Logistics, 32(7), 1407-1429.

Institut Teknologi Kesehatan Malang Widya Cipta Husada (2021). Mempertahankan Kepuasan Konsumen Di Masa Pandemi Covid-19. Available at: http://stikeswch-malang.ac.id/mempertahankan- kepuasan-konsumen-di-masa-pandemi-covid-19/

Jasinskas, E., Streimikiene, D., Svagzdiene, B., \& Simanavicius, A. (2016). Impact of hotel service quality on the loyalty of customers. Economic Research-Ekonomska Istrazivanja, 29(1), 559-572.

Jones, T. O., \& Sasser, W. E. (2009). Http://Hbr.Harvardbusiness.Org/1995/11/Why-

Satisfied-Customers-. Journal Harvard Business, 112. http://hbr.harvardbusiness.org/1995/11/whysatisfied-customers-defect/ar/pr

Kandampully, J., \& hu, H. H. (2007). Do hoteliers need to manage image to retain loyal customers? International Journal of Contemporary Hospitality Management, 19(6), 435-443.

Kandampully, J., \& Suhartanto, D. (2000). Customer loyalty in the hotel industry: The role of customer satisfaction and image. International Journal of Contemporary Hospitality Management, 12(6), 346351.

Katadata (2020). Tren Bisnis Kedai Kopi 2021: Harga Makin Terjangkau, Kualitas Bersaing. Available at: https://katadata.co.id/ekarina/berita/5fa93cddb3869/t ren-bisnis-kedai-kopi-2021-harga-makin-terjangkaukualitas-bersaing

Khan, M. M., \& Fasih, M. (2014). Impact of service quality on customer satisfaction and customer loyalty: Evidence from banking sector. Pakistan Journal of Commerce and Social Sciences, 8(2), 331354.

Kheng, L. L., Mahamad, O., Ramayah, T., \& Mosahab, R. (2010). The Impact of Service Quality on Customer Loyalty: A Study of Banks in Penang, Malaysia. International Journal of Marketing Studies, 2(2), 57-66.

Kim, S. H., Kim, M. S., \& Lee, D. H. (2016). The effects of personality traits and congruity on customer satisfaction and brand loyalty: Evidence from coffee shop customers. In Advances in Hospitality and Leisure, 12, 3-33.

Kim, W. G., Ng, C. Y. N., \& Kim, Y. soon. (2009). Influence of institutional DINESERV on customer satisfaction, return intention, and word-of-mouth. International Journal of Hospitality Management, 28(1), 10-17.

Kususmasasti, I., Andarwati, \& Hadiwidjojo, D. (2017). Pengaruh Kualitas Produk Dan Layanan Terhadap Loyalitas Pelanggan Coffee Shop. Ekonomi Bisnis, 22(2), 123-129.

Lee, W. S., Moon, J., \& Song, M. (2018). Attributes of the coffee shop business related to customer satisfaction. Journal of Foodservice Business Research, 21(6), 628-641. 
J.A. Pesoa, B. Kristyanto, and P.K. Dewa

Mafini, C., \& Dhurup, M. (2015). Drivers of customer loyalty in South African retail stores. Journal of Applied Business Research, 31(4), 1295-1310.

Majid, M. A. A., Samsudin, A., Noorkhizan, M. H. I., Zaki, M. I. M., \& Bakar, A. M. F. A. (2018). Service Quality, Food Quality, Image and Customer loyalty: An Empirical Study at a Hotel Restaurant. International Journal of Academic Research in Business and Social Sciences, 8(10), 1432-1446

Mang'unyi, E. E., Khabala, O. T., \& Govender, K. K. (2018). Bank customer loyalty and satisfaction: the influence of virtual e-CRM. African Journal of Economic and Management Studies, 9(2), 250-265.

Martey, E. M. (2014). The Relationship between Customer Retention and Customer Loyalty in the Restaurant Industry in Ghana. International Journal of Research (IJR), 1(8), 51-66.

Me'ndez, J. L., Oubiña, J., \& Rubio, N. (2011). The relative importance of brand packaging, price and taste in affecting brand preferences. British Food Journal, 113(10), 1229-1251.

Meredith J. Theory building through conceptual methods. International Journal of Operations \& Production Management, 13(5), 3-11

Miranda, S., Tavares, P., \& Queiró, R. (2018). Perceived service quality and customer satisfaction: A fuzzy set QCA approach in the railway sector. Journal of Business Research, 89, 371-377.

Mohamud, S. S., Khalifa, G. S. A., \& Abuelhassan, A. E. (2017). Investigating the Antecedents of Coffee Shop. International Journal on Recent Trends in Business and Tourism, 1, 1-14.

Normann, R. (1991). Service Management: Strategy and Leadership in Service Business. France: Wiley.

Parsa, H. G., Self, J., Dutta, K., \& Gregory, A. (2012). Consumer behaviour in restaurants: assessing the importance of restaurant attributes in consumer patronage and willingness to pay. Journal of Services Research, 12(2), 29-56.

Peng, N., \& Chen, A. H. (2015). Diners' loyalty toward luxury restaurants: the moderating role of product knowledge. Marketing Intelligence \& Planning, 33(2), 179-196.

Pleshko, L. P., \& Heiens, R. A. (2015). Customer satisfaction and loyalty in the Kuwaiti retail services market: why are satisfied buyers not always loyal buyers? International Review of Retail, Distribution and Consumer Research, 25(1), 55-71.

Roy, S. K., Shekhar, V., Lassar, W. M., \& Chen, T. (2018). Customer engagement behaviors: The role of service convenience, fairness and quality. Journal of
Retailing and Consumer Services, 44, 293-304.

Ryu, K., Lee, H. R., \& Kim, W. G. (2012). The influence of the quality of the physical environment, food, and service on restaurant image, customer perceived value, customer satisfaction, and behavioral intentions. International Journal of Contemporary Hospitality Management, 24(2), 200223

Saleem, H., \& Raja, N. S. (2014). The impact of service quality on customer satisfaction, customer loyalty and brand image: Evidence from hotel industry of Pakistan. Middle - East Journal of Scientific Research, 19(5), 706-711.

Satuan Tugas Penanganan COVID-19 (2020). Perkembangan Kasus Terkonfirmasi Positif Covid-19 Per-Hari. Available at: https://covid19.go.id/petasebaran

Sekretariat Kabinet Republik Indonesia. (2020). Presiden Tetapkan Bencana Nonalam Penyebaran Covid-19 sebagai Bencana Nasional. https://setkab.go.id/presiden-tetapkan-bencananonalam-penyebaran-covid-19-sebagai-bencananasional/

Sekretariat Presiden. (2021). Pemerintah Perkuat PPKM Mikro dalam Dua Pekan ke Depan. Available at: https://www.presidenri.go.id/siaranpers/pemerintah-perkuat-ppkm-mikro-dalam-duapekan-ke-depan/

Shin, C.-S., Hwang, G.-S., Lee, H.-W., \& Cho, S.-R. (2015). The Impact of Korean Franchise Coffee Shop Service Quality and Atmosphere on Customer Satisfaction and Loyalty. The East Asian Journal of Business Management, 5(4), 47-57.

Sia, F. T., \& Subagio, H. (2013). Analisa Pengaruh Price Service Quality, Dan Corporate Image Terhadap Customer Loyalty Dengan Customer Satisfaction Sebagai Variabel Intervening Konsumen Ipo Korean Cafe Dan Restaurant Surabaya. Jurnal Manajemen Pemasaran, 1(1), 1-8.

Suhud, U., Allan, M., Wibowo, S. F., Sabrina, E., \& Willson, G. (2020). Measuring customer satisfaction of a café and coffee shop colony at a traditional market. Journal of Foodservice Business Research, 23(1), 78-94.

Susanty, A., \& Kenny, E. (2015). The relationship between brand equity, customer satisfaction, and branf loyalty on coffee shop: Study of Excelso and Starbucks. Asean Marketing Journal, 7(1), 14-27.

Tan, T. M., Ismail, H. Bin, \& Rasiah, D. (2011). Hierarchical Chain Of Consumer-Based Brand Equity: Review From The Fast Food Industry. International Business \& Economics Research Journal, 10(9), 67-80. 
Toffin (2020). Toffin Indonesia Merilis Riset "2020 Brewing in Indonesia". Available at: https://insight.toffin.id/toffin-stories/toffinindonesia-merilis-riset-2020-brewing-in-indonesia/

Uddin, M. B. (2019). Customer loyalty in the fast-food restaurants of Bangladesh. British Food Journal, 121(11), 2791-2808.

Wang, E. S. T., \& Yu, J. R. (2016). Effect of product attribute beliefs of ready-to-drink coffee beverages on consumer-perceived value and repurchase intention. British Food Journal, 118(12), 2963-2980.

Yong-Ki Lee. (2005). The Relative Impact of Service Quality on Service Value, Customer Satisfaction, and Customer Loyalty in Korean Family Restaurant Context. International Journal of Hospitality \& Tourism Administration, 6(1), 27-51.

Zeithaml, V. A., Berry, L. L., \& Parasuraman, A. (1988). Communication and Control Processes in the Delivery of Service Quality. Journal of Marketing, $52(2), 35-48$. 
This page is intentionally left blank 